\title{
KEBIJAKAN KRIMINAL DALAM PENANGGULANGAN TINDAK PIDANA DAN KENAKALAN SISWA SMA : SUATU KAJIAN TENTANG PENERAPAN TEORI KONTROL SOSIAL DAN KEARIFAN LOKAL DI BALI ${ }^{1}$
}

\author{
Oleh: \\ GDE MADE SWARDHANA², IDA BAGUS SURYA DHARMA JAYA, \\ I GUSTI AYU PUTRI KARTIKA
}

\begin{abstract}
ABTSRAK
Juvenile delinquency is a symptom of social and has raised concerns among parents in particular and society in general. These forms of behavior such as child delinquency abuse of narcotic and psychotropic drugs, free sex, fights among teenagers of the village, street racing, began to adorn the Balinese order changes gradually. These symptoms seem to always just show itself as an actual problem that is typical in each period of time and therefore be interesting to be examined. Community structure that changes caused by pressure or offered options that ultimately became plural and multicultural Bali. Resolution of the problem certainly must be associated with a Balinese local wisdom itself.

The problem is formulated: (1) why the theory of social control is the most appropriate theory used to cope with children's Misbehavior in Bali?; (2) How the pattern of juvenile delinquency prevention in Bali with the use of local wisdom?

The approach used in this study is the non doctrinal approach (socio-legal approach). In principle the socio-legal study is the study of the law, based on social sciences methodology in the broad sense. This research included in aggregate research tradition between qualitative research and quantitative research is often known for its mix of research, with the perspective approach to Criminology.

(1) the theory of social control, as compared to the theory of social disorganization theories of deviant behavior in criminology, social control theory most appropriate use in tackling child because, while a strong social bonds between the children with peers, peer group, parents, school teachers, community leaders, religious figures, children undoubtedly will not do deviate behavior. Although his theory of social control in the West but its implementation against children in Bali is more focused than the other theories are, of course, the addition of the elements contained in the theory of social control, such as Attachment, Commitment, Involvement, and Belief, is associated with the local wisdom Balinese people strongly support the strengthening of social control theory; (2) the pattern of juvenile delinquency prevention in General to use the model of non-penal and penal. The pattern of non penal in tackling child delinquency through local wisdom like tri hita karana, tri kaya parisudha, tri tat twam asi, and others, the Balinese social control can prevent or cope with a minimum of child delinquency in Bali.
\end{abstract}

Keywords: Juvenile delinquency, Social control theory, patern for prevention, Balinese local wisdom.

Karya ilmiah ini merupakan hasil penelitian yang di biayai dari dana Dipa BLU Program Studi Magister(S2) Ilmu Hukum PPS UNUD dengan SK Rektor Nomor: 2116/UN.14.4/HK/2014, telah di presentasikan dalam seminar/FGD di Program Magister (S2) Ilmu Hukum pada tanggal 31 Oktober 2014
Penulis adalah Dosen pada Program Studi Magister (S2) Ilmu Hukum Program Pascasarjana Unud, sedangkan penulis ketiga adalah Mahasiswa Program Doktor Ilmu Hukum Program Pascasarjana Unud. 


\section{PENDAHULUAN}

\section{Latar Belakang Masalah}

Perilaku delinkuen anak terutama pada anak-anak siswa sekolah menengah atas yang terjadi di Bali nampak mengabaikan ikatan sosial yang telah di bangun secara turun temurun, anak-anak sudah tidak terikat lagi pada orang tua, guru, dan lingkungannya. Elemen teori kontrol sosial oleh Travis Hirschi berupa attachment, commitment, involvement, belief, telah diabaikan oleh anak-anak di sekolah maupun di lingkungan masyarakat.

Memperhatikan

kondisi penanggulangan kenakalan anak lewat jalur penal pada satu sisi dan tuntutan masyarakat internasional tentang perlindungan hak-hak anak delinkuen dalam proses peradilan anak pada pihak lain, mendorong perlunya diperhatikan sisi lain dari politik kriminal berupa kegiatankegiatan nonpenal (nonhukum pidana) dalam konteks penanggulangan perilaku delinkuen anak di masyarakat. Kegiatan nonpenal berupa pengurangan faktorfaktor potensial kriminogen, maka sangat mendukung bila dilakukan pemahaman terhadap gejala sosial berupa perilaku delinkuen anak, termasuk faktor-faktor korelasional yang melatarbelakanginya yang tentunya mengarah pada pembahasan pada ilmu tentang kejahatan. Melalui telaah dan kajiaan kriminologi orang dapat memperoleh pemahaman tentang gejala sosial berupa kejahatan dan perilaku delinkuen anak ${ }^{3}$.

3 Ilmu kriminologi mengenal adanya tiga aliran pemikiran, aliran pemikiran klasik, terfokus pada asumsi dasar bahwa manusia berkehendak bebas, perilaku manusia semata-mata dipengaruhi akal dan rasionya (indeterminisme), kriminologi mengarahkan
Selain penanggulangan melalui non-penal juga diupayakan melalui kearifan lokal masyarakat Bali. Kearifan lokal masyarakat Bali dapat diklasifikasikan ke dalam konsep Tri hita karana, panca sradha, panca yadnya, karmaphala, tat twam asi, dan lain-lain.

Melalui pemahaman kriminologi, dapat diungkap kenakalan anak di Bali yang berbeda dengan kenakalan anak pada umumnya. Dari perilaku yang berbeda menyebabkan lemahnya ikatan sosial yang berakibat terjadinya kenakalan anak, dan kemudian dapat pula dikaji apakah dengan pemahaman teori kontrol sosial dapat digunakan menanggulangi kenakalan anak. Di samping itu, apa ada korelasional antara elemen ikatan sosial terhadap kenakalan anak, juga dianalisis ikatan sosial dalam teori kontrol terhadap kenakalan anak di Bali. Membahas pula tentang polapenanggulangan kenakalan anak di Bali dengan penggunaan kearifan lokal seperti filosofi dalam Tri Hita Karana.

studinya pada penology; aliran pemikiran positif, terfokus pada asusmsi bahwa manusia tidak berkehendak bebas, perilaku manusia dipengaruhi faktor-faktor di luar kontrolnya - fisik, kejiwaan serta lingkungan sosiokulturalnya (determinisme), kriminologi mempelajari hubungan faktor-faktor tersebut dengan terjadinya kejahatan, atau mempelajari sebab-sebab terjadinya kejahatan (etiologi criminal); aliran pemikiran kritis, terfokus pada asumsi dasar bahwa perilaku manusia tidak hanya ditentukan oleh peranan kondisi-kondisi sosial akan tetapi juga peranan individu dalam menangani, menafsirkan dan berinteraksi dengan kondisi-kondisi bersangkutan, kriminologi mempelajari proses yang mempengaruhi pembentukan undang-undang yakni dijadikannya perbuatan tertentu sebagai kejahatan dan proses bekerjanya hukum pidana yakni proses-proses yang menjadikannya orang-orang tertentu sebagai penjahat (sosiologi hukum pidana) (IS Susanto, Kejahatan Korporasi, Semarang, Badan Penerbit UNDIP, 1995: 6-13) 
Di sinilah lalu ada kebutuhan untuk melakukan pengujian teori tentang kejahatan dan perilaku delinkuen anak (yang umumnya berasal dari "barat") dalam konteks masyarakat Bali. Masalahnya adalah : (a) teori kriminologi manakah yang akan diuji?, dan (b) mengapa masyarakat Bali yang dijadikan uji penelitian?.

Masalah pertama dapat dijelaskan : teori kriminologi yang akan diuji adalah teori kriminologi yang lahir dari kondisi masyarakat yang mengalami disorganisasi (disorganized society) yakni teori Kontrol Sosial yang dikemukakan oleh Travis Hirschi dikenal Ikatan Sosial (social bond). Masalah kedua dapat dijelaskan : masyarakat Bali sejak dahulu dikenal sebagai masyarakat yang ramah, rukun, dan menerima masyarakat lain - pengaruh pariwisata - ke dalam kehidupan bermasyarakat. Pola hidup solidaritas amat tinggi, salunglung sabayantaka, paras-paros sarpanaya, segilik seguluk, serta agawe suka nikang rat, konsep bermasyarakat yang dijunjung tinggi masyarakat Bali masih dipegang teguh dan tertuang dalam ajaran Tri Hita Karana , suatu konsep bermasyarakat yang dijunjung tinggi menjadikan Bali semakin dikenal masyarakat luas. Ikatan sosial masyarakat Bali satu sama lain saling merasa sebagai bagian dari masyarakatanya. Di dalam Tri Hita Karana sudah terkandung Nilai-nilai, Norma, dan Pelembagaan, hal inilah yang sering disebut sebagai kearifan lokal masyarakat Bali

\section{Rumusan Masalah}

(a) Bagaimanakah penerapan teori kontrol sosial dalam menjelaskan penanggulangan tindak pidana dan kenalalan anak di Bali ? (b) Bagaimanakah peran kearifan lokal dalam penanggulangan tindak pidana dan kenakalan anak di Bali?

\section{METODE PENELITIAN}

a. Metode Pendekatan

Menjawab apa yang menjadi tujuan pengkajian penelitian ini, maka studi ini menerapkan pendekatan kriminologis 4 . Terdapat tiga paradigma utama dalam kriminologimasing-masingmengembangkan model analisa dan metode penelitian tentang gejala kejahatan. Ketiga paradigma tersebut adalah paradigma positivisme, interaksionisme, dan sosialis. Masingmasing paradigm tersebut berkembang melalui perspektif masing-masing satu sama lain berbeda. Paradigma positivisme dilatarbelakangi oleh perspektif konsensus; paradigma interaksionis dilatarbelakangi oleh perspektif pluralism; sedangkan paradigma sosialis dilatarbelakangi oleh perspektif konflik. Uraian mendalam tentang ketiga paradigm dan perspektif tersebut yang dipergunakan untuk mempelajari gejala kejahatan di masyarakat dikaji lebih dalam oleh Michalowski (1977)5.

Paradigma-paradigma dalam kriminologi tersebut oleh Michalowski dijelaskan: paradigm positivism mempunyai ciri adanya kepercayaan bahwa metode

Edwin H Sutherland (1995) mengklasifikasikan bagian-bagian pokok dari ilmu kriminologi adalah (a) penology, (b) Etiologi Kriminal, dan (c) Sosiologi Hukum Pidana, dalam Principle of Criminology, revised by Donald R Creseey, Philadelphia; JB Lipincolt Co, 1995 : 80-83. Prof Soedarto, sering mengemukakan bahwa Kriminologi sebagai empirisnya hukum pidana.

Muhammad Mustofa, Loc cit, hal. 25 
ilmiah untuk memperoleh semua gejala haruslah dilihat sebagai hasil dari adanya hubungan sebab akibat yang merupakan hukum alam. Dalam mempelajari kejahatan, positivisme menekankan pada sifatsifat asasi dari manusia. Sementara itu, perspektif interaksionisme tidak melihat gejala kejahatan sebagai sifat asasi manusia tetapi lebih merupakan suatu katagori yang diberikan oleh orang lain. Berbagai tingkah laku dikatagorikan sebagai kejahatan karena kita mendefinisikannya demikian. Paradigma sosialis melihat kejahatan sebagai tingkah laku yang didefinisikan dan diperlakukan oleh kelompok yang mempunyai kekuasaan dominan sebagai tingkah laku yang membahayakan kepentingannya ${ }^{6}$.

b. Identifikasi Variabel

Perlakuannya

Penelitian ini mengkaji perilaku kenakalan anak sebagai gejala sosial dengan mengambil lokasi penelitian di Bali. Studi demikian memperlakukan teori Kontrol Sosial dengan elemen-elemen Attachment yang diperlakukan sebagai Variabel Bebas (X1), Commitment yang diperlakukan sebagai Variabel Bebas (X2), Involvement yang diperlakukan sebagai Variabel Bebas (X3), dan Belief yang diperlakukan sebagai Variabel Bebas (X4), yang keberadaannya berkaitan erat dengan gejala kenakalan anak di Bali yang diperlakukan sebagai Variabel Terikat (dengan simbol Y).

Attachment (X1) selanjutnya diterjemahkan menjadi beberapa indikator yaitu (a) keterikatan pada orang tua,

Muhammad Mustofa, Loc cit, hal25 (b) keterikatan pada guru sekolah, (c) keterikatan pada teman sebaya, Commitment (X2) diterjemahkan menjadi indikator yaitu (a) perhitungan untung rugi (manfaat) keterlibatan seseorang dalam kenakalan anak, Involvement (X3) diterjemahkan ke dalam beberapa indikator, yaitu (a) apabila disibukkan dalam berbagai kegiatan/aktivitas konvensional, maka anak tidak akan pernah sempat berpikir apalagi melibatkan diri dalam kejahatan, sementara Belief (X4) diukur dari aspek sikap dan kepatuhannya pada nilai-nilai religious dan adat istiadat yang berhubungan dengan masalah kenakalan anak.

c. Penentuan Sample

Data dikumpulkan tahun 2013 berdasarkan pengakuan diri responden (self report) yang populasinya sebanyak 300 orang siswa-siswi SMA kelas III di seluruh Bali dan ditentukan secara purposive masing-masing Kabupaten / Kota di Bali berjumlah 9 kabupaten / Kota) dengan demikian masing-masing Kabupaten / Kota samplenya sebanyak 30 orang, yang terdiri dari siswa/i SMA yang berada di tengah kota sebanyak 15 orang dan siswa/i SMA yang berada di pedesaan sebanyak 15 orang pula, kecuali kota Denpasar sebanyak 30 orang

d. Tempat dan Waktu Penelitian

Tempat dan waktu penelitian ini dilakukan di SMA-SMA se Bali meliputi wilayah-wilayah penelitian tersebut adalah di Kota Denpasar, Kabupaten Badung, Kabupaten Gianyar, Kabupaten Klungkung, Kabupaten Bangli, Kabupaten Karangasem, Kabupaten Buleleng, Kabupaten Tabanan, dan Kabupaten Jembrana 
e. Metode Pengumpulan Data

Data penelitian ini terdiri atas data sekunder dan data primer. Data sekunder dikumpulkan dengan cara pemahaman bahan-bahan pustaka dan dokumen-dokumen yang dianggap gayut dengan permasalahan yang di bahas dalam studi ini. Data primer dikumpulkan dengan cara SelfReport Studies (Studi Pengakuan Diri), yaitu suatu cara pengumpulan data yang dilakukan dengan cara mewawancarai sejumlah siswa SMA, berdasarkan pengalaman dan pengakuan pribadi.

f. Metode Pengolahan dan Analisis Data

Data diperoleh dimulai dari memeriksa data (editing) yang terkumpul. Setelah proses editing data selesai, selanjutnya memberi kode (coding) lalu dipindahkan ke dalam matriks data (coding sheet), maka tahap berikutnya adalah melakukan tabulasi data, yang hasil selengkapnya disajikan dalam bentuk tabel. Data penelitian yang bersifat sosiologis makro, dianalisis dengan analisis kuantitatif statistik, selain itu digunakan tehnik Pengujian Korelasi Variabel (ada yang tunggal dan jamak) maka digunakan Pengujian Yulis' $Q$ sebagai tehnik pengujian korelasi yang mampu menganalisis tidak saja korelasi tunggal pada dua variabel tetapi sekaligus beberapa korelasi dalam tiga, empat atau lebih variabel.

Di bawah ini dikemukakan rumus Yulis' $Q$ sebagai berikut :

Keterangan :

Q xy : Nilai Yulis'Q yang dicari

a, b, c, dan d : bilangan yang diperoleh dalam kotak a, b, c, d.

Oleh karena variabel yang diujikan, dikatagorikan menjadi dua, maka kalau menguji korelasi dua variabel, pengujiannya menggunakan Tabel empat sel, seperti di bawah ini :

Tabel 2. KOTAK EMPAT SEL UNTUK PENGUJIAN DUA VARIABEL

\begin{tabular}{|c|c|c|c|}
\hline \multirow{2}{*}{$\begin{array}{c}\text { Elemen } \\
\text { Kontrol } \\
\text { Sosial }\end{array}$} & \multicolumn{2}{|c|}{ Jenis Kenakalan } & \multirow[b]{2}{*}{ Total } \\
\hline & $\begin{array}{l}\text { Tindak } \\
\text { Pidana }\end{array}$ & Kenakalan & \\
\hline Lemah & A & B & $a b$ \\
\hline Kuat & C & $d$ & $c d$ \\
\hline Jumlah & ac & bd & $\begin{array}{l}a b+c d \\
a c+b d=N\end{array}=$ \\
\hline
\end{tabular}

Berdasarkan metode Yulis' $Q$, hasil penghitungan ini diuji dengan kriteria pada Tabel Convensi Nilai-nilai Q, maka apabila hasilnya mendekati 1 (satu) di dapat hubungan yang positif, bilamana hasilnya mendekati -1 (min satu), maka terjadi hubungan yang negatif, dan apabila hasilnya 0 (nol) ini berarti tidak terjadi hubungan sama sekali.

$$
\begin{aligned}
& (\text { b } x \text { c) }-(\text { a } x d) \\
& \text { Q xy = } \\
& (b \times d)+(a \times d)
\end{aligned}
$$

\section{HASIL DAN PEMBAHASAN}

1. Teori Kontrol Sosial dalam menanggulangi Kenakalan Anak Di Bali

a. Identifikasi responden yang dikatagorisasikan melakukan Tindak Pidana dan Kenakalan Anak

Sebelum membahas permasalahan mengenai korelasi ikatan sosial (social bond) 
dengan kenakalan anak di Bali, terlebih dahulu akan disajikan pengkatagorisasian usia responden antara umur 16 - 18 tahun anak-anak SMA, kondisi atau keadaan orang tua responden, dan jumlah saudara responden. Hal ini dimaksudkan sebagai tahap perkenalan terhadap anak-anak SMA se Bali yang dijadikan responden untuk mengetahui hal-hal yang berkaitan dengan ikatan sosial.

Responden anak-anak SMA se Bali yang diteliti sebanyak 300 orang yaitu anak-anak yang berada pada SMA. Pengkatagorisasian ini hanyalah untuk memudahkanpengklasifikasianusia sehingga kelompok usia tersebut menunjukkan responden berada di semua kelas.

Selanjutnya tampilan Tabel- tabel yang terkait anak yang melakukan Tindak Pidana dan Kenakalan. Jadi kedua perbuatan baik yang bertentangan dengan hukum atau melawan hukum maupun bertentangan dengan norma kehidupan masyarakat.

Tabel 1. PERILAKU RESPONDEN YANG MENGARAH KE KATAGORISASI TINDAK PIDANA DAN KENAKALAN $(n=300)$

\begin{tabular}{|l|l|c|c|}
\hline \multirow{2}{*}{ NO } & \multirow{2}{*}{ KATAGORISASI KENAKALAN } & \multicolumn{2}{|c|}{ FREKUENSI } \\
\cline { 3 - 4 } & & $\mathrm{n}$ & $\%$ \\
\hline 1 & Tindak pidana & 136 & 45 \\
\hline 2 & Kenakalan & 164 & 55 \\
\hline \multicolumn{2}{|c|}{ JUMLAH } & 300 & 100 \\
\hline
\end{tabular}

Katagorisasikan perilaku anak menjadi dua yakni perilaku yang menjurus ke Tindak Pidana dan perilaku anak yang menjurus ke Kenakalan Anak. Pembagian katagori ini dimaksudkan perilaku anak yang mengarah ke perbuatan tindak pidana adalah perbuatan yang telah diatur dan pengaturan tersebut memberikan suatu larangan maupun sanksi bagi siapa yang melanggarnya dan perbuatan tersebut dituangkan di dalam peraturan perundang-undangan yang secara konvensional diatur di dalam Kitab Undang undang Hukum Pidana (KUHP).

Tabel 2. PERILAKU RESPONDEN YANG MENGARAH TINDAK PIDANA

\begin{tabular}{|l|l|c|c|}
\hline \multirow{2}{*}{ NO } & \multirow{2}{*}{ JENIS TINDAK PIDANA } & \multicolumn{2}{|c|}{ FREKUENSI } \\
\cline { 3 - 4 } & & $n$ & $\%$ \\
\hline 1 & Pencurian & 15 & 11 \\
\hline 2 & Perjudian & 36 & 26 \\
\hline 3 & Penganiayaan & 6 & 4 \\
\hline 4 & Penipuan & 18 & 13 \\
\hline 5 & Penggelapan & 20 & 15 \\
\hline 6 & Kesusilaan & 5 & 4 \\
\hline 7 & Pemerasan & 34 & 25 \\
\hline 8 & Narkotika / Psikotropika & 2 & 1 \\
\hline & JUMLAH & 136 & 100 \\
\hline
\end{tabular}

Responden berjumlah 300 orang mengaku pernah melakukan perbuatan yang dapat diklasifikasikan perbuatan pidana sebanyak 136 orang, seperti pemerasan (bulying) 34 orang (25\%), perjudian36 orang $(26 \%)$, penggelapan 20 orang (15 $\%$ ), penipuan 18 orang (13\%), pencurian 15 orang $(11 \%)$, penganiayaan 6 orang $(4 \%)$, kesusilaan 5 orang (4\%), dan penyalahgunaan narkotika/psikotropika sebanyak 2 orang atau $1 \%$ ).

Selanjutnya dikemukakan tabel responden yang mengarah ke katagorisasi kenakalan.

Tabel 3. PERILAKU RESPONDEN YANG MENGARAH KENAKALAN 
(UDAYANA MASTER LAW JOURNAL)

\begin{tabular}{|c|l|c|c|}
\hline \multirow{2}{*}{ NO } & \multirow{2}{*}{ KATAGORISASI KENAKALAN } & \multicolumn{2}{|c|}{ FREKUENSI } \\
\cline { 3 - 4 } & & $n$ & $\%$ \\
\hline 1 & Perkelahian & 19 & 12 \\
\hline 2 & Upload Porno & 20 & 12 \\
\hline 3 & Tempat terlarang bagi anak-anak & 8 & 5 \\
\hline 4 & Merokok & 41 & 25 \\
\hline 5 & Minuman beralkohol & 25 & 15 \\
\hline 6 & Mabuk-mabukan & 26 & 16 \\
\hline 7 & Ngebut di jalanan & 17 & 10 \\
\hline 8 & Bolos sekolah & 8 & 5 \\
\hline & JUMLAH & 164 & 100 \\
\hline
\end{tabular}

Anak dapat dikatagorisasikan kedalam kenakalan terdiri dari responden pernah merokok 41 orang (25\%), mabuk-mabukan 26 orang (16\%), minum-minuman berakohol 26 orang (16\%), meng-upload gambar porno 20 orang $(12 \%)$, ngebut di jalanan 17 orang (10\%), pernah berkelahi 19 orang (12\%), mengunjungitempat-tempatyang seharusnya belum boleh dikunjungi anak-anak, 8 orang (5\%), dan bolos sekolah 8 orang (5\%).

b. Korelasi antara Elemen-elemen Kontrol Sosial dengan Kenakalan Anak di Bali

Di bawah ini merupakan Katagorisasi Elemen-elemen Kontrol Sosial yang dikualifikasikan ke dalam Variabel X sebagai Variabel Bebas.

Tabel 4. HUBUNGAN

ANTARA KENAKALAN ANAK DENGAN ATTACHMENT ORANG TUA

\begin{tabular}{|c|c|c|c|c|c|}
\hline \multirow{2}{*}{$\begin{array}{c}\text { KETERIKATAN } \\
\text { PADA ORANG } \\
\text { TUA }\end{array}$} & \multicolumn{2}{|c|}{ JENIS KENAKALAN } & \multirow[b]{2}{*}{ TOTAL } & \multirow[b]{2}{*}{$Q x y$} & \multirow[b]{2}{*}{ KK/CC } \\
\hline & $\begin{array}{c}\text { Tindak } \\
\text { Kriminal }\end{array}$ & Kenakalan & & & \\
\hline LEMAH & $74(\mathrm{a})$ & $32(b)$ & 106 & \multirow{3}{*}{$-0,66236$} & \multirow{3}{*}{$\begin{array}{c}\text { Hubungan } \\
\text { negatif yang } \\
\text { mantap }\end{array}$} \\
\hline KUAT & $62(c)$ & 132 (d) & 194 & & \\
\hline Jumlah & 136 & 164 & 300 & & \\
\hline
\end{tabular}

$Q$ xy = Nilai Yulis' $Q$ yang dicari

KK/ CC $=$ Koefisien Korelasi / Coeficient Correlation
Jika dikaitkan dengan Tabel tentang Nilai Koefisien Korelasi (Coeficient of Correlation) maka diperoleh hubungan negatif yang mantap, artinya bahwa anak-anak dalam perilakunya pernah melakukan kenakalan tetapi masih mantap keterikatannya dengan orang tuanya. Asumsinya adalah bahwa semakin tinggi (kuat-132) tingkat keterikatannya pada orang tua maka semakin rendah (lemah-32) anak melakukan kenakalan. Namun sejatinya ikatan sosial (social bond) terhadap orang tua begitu besar.

Tabel 5.

HUBUNGAN ANTARA KENAKALAN ANAK DENGAN ATTACHMENT GURU

\begin{tabular}{|c|c|c|c|c|c|}
\hline \multirow{2}{*}{$\begin{array}{l}\text { KETERIKATAN } \\
\text { PADA GURU }\end{array}$} & \multicolumn{2}{|c|}{ JENIS KENAKALAN } & \multirow[b]{2}{*}{ TOTAL } & \multirow[b]{2}{*}{$Q x y$} & \multirow[b]{2}{*}{$\mathrm{KK} / \mathrm{CC}$} \\
\hline & Tindak Pid & Kenakalan & & & \\
\hline LEMAH & 85 (a) & $29(b)$ & 114 & \multirow{3}{*}{$-0,77165$} & \multirow{3}{*}{$\begin{array}{c}\text { Hubungan } \\
\text { negatif } \\
\text { yang } \\
\text { sangat } \\
\text { kuat }\end{array}$} \\
\hline KUAT & 51 (c) & 135 (d) & 186 & & \\
\hline Jumlah & 136 & 164 & 300 & & \\
\hline
\end{tabular}

Tabel di atas jika dikaitkan dengan Tabel Nilai Koefisien Korelasi (Coeficient of Correlation) maka diperoleh hubungan negatif yang sangat kuat, artinya bahwa siswa dalam perilakunya pernah melakukan kenakalan tetapi sangat kuat keterikatannya dengan para guru di sekolahnya.adlah berbeda dengan keterikatan pada orang tuanya, namun tidaklah demikian jauhnya ikatan antara kedua attachment tersebut. Bila diasumsikan dapat diperoleh semakin tinggi (kuat-135) tingkat keterikatannya pada guru maka semakin rendah (lemah-29) 
pulalah anak melakukan kenakalan. Namun sejatinya ikatan sosial (social bond) terhadap guru di sekolah begitu sangat kuat.

Tabel 6.

HUBUNGAN ANTARA KENAKALAN ANAK DENGAN ATTACHMENT KEGIATAN KONVENSIONAL

\begin{tabular}{|c|c|c|c|c|c|}
\hline \multirow[b]{2}{*}{$\begin{array}{l}\text { KETERIKATAN } \\
\text { PADA KEGIATAN } \\
\text { KONVENSIONAL }\end{array}$} & \multicolumn{2}{|c|}{ JENIS KENAKALAN } & \multirow[b]{2}{*}{ TOTAL } & \multirow[b]{2}{*}{ Qxy } & \multirow[b]{2}{*}{$\mathrm{KK} / \mathrm{CC}$} \\
\hline & $\begin{array}{c}\text { Tindak } \\
\text { Kriminal }\end{array}$ & Kenakalan & & & \\
\hline LEMAH & 86 (a) & 44 (b) & 130 & \multirow{3}{*}{$-0,64856$} & \multirow{3}{*}{$\begin{array}{c}\text { Hubungan } \\
\text { negatif } \\
\text { yang } \\
\text { mantap }\end{array}$} \\
\hline KUAT & $50(c)$ & 120 (d) & 170 & & \\
\hline Jumlah & 136 & 164 & 300 & & \\
\hline
\end{tabular}

Paparan tabel di atas dikaitkan dengan Tabel Nilai Koefisien Korelasi (Coeficient of Correlation) maka diperoleh hubungan negatif yang mantap, artinya bahwa siswa pernah melakukan kenakalan anak, tetapi keterikatannya dengan kegiatan konvensional seperti upacara bendera, piket sekolah, perlombaan, mengerjakan pekerjaan rumah (PR) baik secara berkelompok maupun individu menunjukkan hubungan yang mantap di sekolahnya. Bila diasumsikan dapat dikatakan semakin tinggi (kuat-120) tingkat keterikatannya pada kegiatan konvensional maka semakin rendah (lemah-44) pulalah anak melakukan kenakalan. Sejatinya ikatan sosial (social bond) terhadap kegiatan konvensional di sekolah begitu mantap.

\section{Tabel 7.}

HUBUNGAN ANTARA KENAKALAN ANAK DENGANATTACHMENT PEERGROUP

\begin{tabular}{|c|c|c|c|c|c|}
\hline \multirow{2}{*}{$\begin{array}{c}\text { KETERIKATAN } \\
\text { PADA PEER } \\
\text { GROUP }\end{array}$} & \multicolumn{2}{|c|}{ JENIS KENAKALAN } & \multirow[b]{2}{*}{ TOTAL } & \multirow[b]{2}{*}{ Qxy } & \multirow[b]{2}{*}{$\mathrm{KK} / \mathrm{CC}$} \\
\hline & $\begin{array}{c}\text { Tindak } \\
\text { Kriminal }\end{array}$ & Kenakalan & & & \\
\hline LEMAH & 72 (a) & 46 (b) & 118 & \multirow{3}{*}{$-0,48531$} & \multirow{3}{*}{$\begin{array}{l}\text { Hubungan } \\
\text { negatif } \\
\text { yang } \\
\text { sedang }\end{array}$} \\
\hline KUAT & 64 (c) & 118 (d) & 182 & & \\
\hline Jumlah & 136 & 164 & 300 & & \\
\hline
\end{tabular}

Data di atas jika dikaitkan dengan Tabel Nilai Koefisien Korelasi (Coeficient of Correlation) diperoleh hubungan negatif yang sedang, artinya bahwa siswa dalam berperilaku pernah melakukan kenakalan tetapi keterikatannya dengan peer-group sedang-sedang saja di sekolahnya. Bila diasumsikan dapat diperoleh semakin tinggi (kuat-118) tingkat keterikatannya pada peergroup maka semakin rendah (lemah-46) pula anak melakukan kenakalan. Ikatan sosial (social bond) terhadap peer-group di sekolah biasa (sedang) saja.

\section{Tabel 8.}

HUBUNGAN ANTARA KENAKALAN ANAK DENGAN ATTACHMENT TOKOH AGAMA

\begin{tabular}{|c|c|c|c|c|c|}
\hline \multirow{2}{*}{$\begin{array}{c}\text { KETERIKATAN } \\
\text { PADA TOKOH } \\
\text { AGAMA }\end{array}$} & \multicolumn{2}{|c|}{ JENIS KENAKALAN } & \multirow[b]{2}{*}{ TOTAL } & \multirow[b]{2}{*}{ Qxy } & \multirow[b]{2}{*}{$K K / C C$} \\
\hline & $\begin{array}{c}\text { Tindak } \\
\text { Kriminal }\end{array}$ & Kenakalan & & & \\
\hline LEMAH & $72(\mathrm{a})$ & 55 (b) & 127 & \multirow{3}{*}{$-0,38072$} & \multirow{3}{*}{$\begin{array}{c}\text { Hubungan } \\
\text { negatif } \\
\text { yang } \\
\text { sedang }\end{array}$} \\
\hline KUAT & $64(c)$ & 109 (d) & 109 & & \\
\hline Jumlah & 136 & 164 & 300 & & \\
\hline
\end{tabular}

Tabel Nilai Koefisien Korelasi (Coeficient of Correlation) diperoleh hubungan negatif yang sedang, artinya bahwa siswa dalam berperilaku pernah melakukan kenakalan tetapi keterikatannya 
dengan tokoh agama nampaknya sedangsedang saja di masyarakatnya di mana mereka berada. Bila diasumsikan dapat diperoleh semakin tinggi (kuat-109) tingkat keterikatannya pada tokoh agama maka semakin rendah (lemah-55) pulalah anak melakukan kenakalan. Maka ikatan sosial (social bond) terhadap tokoh agama di masyarakat di mana sisiwa biasa melakukan aktivitasnya menunjukkan analisisnya yang biasa (sedang) saja.

Tabel 9.

HUBUNGAN ANTARA KENAKALAN ANAK DENGAN ATTACHMENT TOKOH MASYARAKAT

\begin{tabular}{|c|c|c|c|c|c|}
\hline \multirow{2}{*}{$\begin{array}{l}\text { KETERIKATAN } \\
\text { PADA TOKOH } \\
\text { MASYARAKAT }\end{array}$} & \multicolumn{2}{|c|}{ JENIS KENAKALAN } & \multirow[b]{2}{*}{ TOTAL } & \multirow[b]{2}{*}{$Q x y$} & \multirow[b]{2}{*}{$\mathrm{KK} / \mathrm{CC}$} \\
\hline & $\begin{array}{l}\text { Tindak } \\
\text { Kriminal }\end{array}$ & Kenakalan & & & \\
\hline LEMAH & 74 (a) & 47 (b) & 121 & \multirow{3}{*}{$-0,49637$} & \multirow{3}{*}{$\begin{array}{c}\text { Hubungan } \\
\text { negatif yang } \\
\text { sedang }\end{array}$} \\
\hline KUAT & $62(c)$ & 117 (d) & 179 & & \\
\hline Jumlah & 136 & 164 & 300 & & \\
\hline
\end{tabular}

Uraian di atas menunjukkan suatu keterikatan yang cukup signifikan. Hal ini secara fisik disadari bahwa anak-anak yang berada di wilayah di mana ia bertempat tinggallebihsering bertemu tokohmasyarakat dibandingkan dengan tokoh agama. Tokoh agama pada umumnya hanya bisa bertemu atau dalam suatu kegiatan hanyalah dalam prosesi upacara keagamaan.

Tokoh masyarakat seperti kelihan adat, kelihan banjar, sesepuh yang disegani, dan tokoh masyarakat lainnya lebih bersentuhan dan secara kontinyuitas lebih sering bertemu atau diberi wejanganwejangan di mana kegiatan anak-anak seperti sekeha teruna-teruni, karang taruna, kelompok remaja lainnya, diberi arahan dan petunjuk oleh tokoh masyarakat tersebut. Jadi kedekatan anak-anak tersebut lebih sering jika dibandingkan dengan dengan kedekatan terhadap tokoh agama. Dikaitkan dengan Tabel Nilai Koefisien Korelasi (Coeficient of Correlation) diperoleh hubungan negatif yang sedang, artinya siswa dalam berperilaku pernah melakukan kenakalan tetapi keterikatannya dengan tokoh masyarakat nampaknya sedangsedang saja di mana mereka berada. Bila diasumsikan dapat diperoleh semakin tinggi (kuat-117) tingkat keterikatannya pada tokoh masyarakat maka semakin rendah (lemah47) pulalah anak melakukan kenakalan. Ikatan sosial (social bond) terhadap tokoh masyarakat di mana siswa biasa melakukan aktivitasnya menunjukkan analisisnya yang biasa (sedang) saja.

Tabel 10.

HUBUNGAN ANTARA KENAKALAN ANAK DENGAN COMMITMENT/ KETERTARIKAN KEGIATAN ORGANISASI SISWA INTRA SEKOLAH (OSIS)

\begin{tabular}{|c|c|c|c|c|c|}
\hline \multirow[b]{2}{*}{$\begin{array}{c}\text { KETERTARIKAN } \\
\text { PADA } \\
\text { KEGIATAN OSIS }\end{array}$} & \multicolumn{2}{|c|}{ JENIS KENAKALAN } & \multirow[b]{2}{*}{ TOTAL } & \multirow[b]{2}{*}{$Q x y$} & \multirow[b]{2}{*}{$\mathrm{KK} / \mathrm{CC}$} \\
\hline & $\begin{array}{c}\text { Tindak } \\
\text { Kriminal }\end{array}$ & Kenakalan & & & \\
\hline NEGATIF & 76 (a) & $32(b)$ & 108 & \multirow{3}{*}{$-0,67871$} & \multirow{3}{*}{$\begin{array}{c}\text { Hubungan } \\
\text { negatif yann } \\
\text { mantap }\end{array}$} \\
\hline POSTIIF & $60(c)$ & 132 (d) & 192 & & \\
\hline Jumlah & 136 & 164 & 300 & & \\
\hline
\end{tabular}

Paparan tabel di atas jika dikaitkan Tabel Nilai Koefisien Korelasi (Coeficient of Correlation) maka diperoleh hubungan negatif yang mantap, artinya siswa pernah melakukan kenakalan, tetapi ketertarikannya pada kegiatan OSIS. Bila diasumsikan 
dapat diperoleh semakin tinggi (positif-132) ketertarikanya pada kegiatan OSIS maka semakin rendah (negatif-32) pulalah anak melakukan kenakalan. Elemen ikatan sosial (social bond) terhadap kegiatan OSIS di sekolah begitu mantap yang menyebabkan anak tidak melakukan perbuatan menyimpang.

Tabel 11.

H U B U N G A N

\begin{abstract}
ANTARA KENAKALAN ANAK DENGAN COMMITMENT / KETERTARIKAN PADA KEGIATAN SEKEHA TERUNA
\end{abstract}

\begin{tabular}{|l|c|c|c|c|c|}
\hline \multirow{2}{*}{$\begin{array}{c}\text { KETERTARIKAN } \\
\text { PADA KEGIATAN } \\
\text { SEKEHA TERUNA }\end{array}$} & \multicolumn{2}{|c|}{ JENIS KENAKALAN } & \multirow{2}{*}{ TOTAL } & Q $x y$ & \multirow{2}{*}{ KK/C C } \\
\cline { 2 - 4 } & $\begin{array}{c}\text { Tindak } \\
\text { Kriminal }\end{array}$ & Kenakalan & & & \\
\hline NEGATIF & 69 (a) & 47 (b) & 116 & & $\begin{array}{c}\text { Hubungan } \\
\text { negatif } \\
\text { yang } \\
\text { sedang }\end{array}$ \\
\hline POSITIF & 67 (c) & 117 (d) & 184 & \multirow{2}{*}{$-0,43878$} & \\
\hline \multicolumn{1}{|c|}{ Jumlah } & 136 & 164 & 300 & & \\
\hline
\end{tabular}

Paparan tabel di atas jika dikaitkan dengan Tabel Nilai Koefisien Korelasi (Coeficient of Correlation) maka diperoleh hubungan negatif yang sedang, artinya bahwa siswa pernah melakukan kenakalan, tetapi ketertarikannya pada kegiatan sekeha Teruna juga tetap dilakukannya. Bila diasumsikan dapat diperoleh semakin tinggi (positif-117) ketertarikanya pada kegiatan OSIS maka semakin rendah (negatif-47) pulalah anak melakukan kenakalan. Ikatan sosial (social bond) terhadap ketertarikannya pada kegiatan sekeha Teruna sedang-sedang saja yang menyebabkan anak tidak perlu melakukan kenakalan.

Tabel 12 .

HUBUNGAN ANTARA KENAKALAN ANAK DENGAN COMMITMENT / KETERTARIKANNYA PADA KEGIATAN ORGANISASI KEMASYARAKATAN

\begin{tabular}{|c|c|c|c|c|c|}
\hline \multirow{2}{*}{\begin{tabular}{|c|} 
KETERTARIKAN \\
PADA KEGIATAN \\
ORGANISASI \\
KEMASYARAKATAN
\end{tabular}} & \multicolumn{2}{|c|}{ JENIS KENAKALAN } & \multirow[b]{2}{*}{ TOTAL } & \multirow[b]{2}{*}{ Qxy } & \multirow[b]{2}{*}{$K K / C C$} \\
\hline & $\begin{array}{l}\text { Tindak } \\
\text { Kriminal }\end{array}$ & Kenakalan & & & \\
\hline NEGATIF & 78 (a) & $70(b)$ & 146 & \multirow{3}{*}{$-0,27159$} & \multirow{3}{*}{$\begin{array}{c}\text { Hubungan } \\
\text { negatif } \\
\text { yang } \\
\text { rendah }\end{array}$} \\
\hline POSITIF & $60(c)$ & 94 (d) & 154 & & \\
\hline Jumlah & 136 & 164 & 300 & & \\
\hline
\end{tabular}

Tabel 4 tentang Nilai Koefisien Korelasi diperoleh hubungan negatif yang rendah, artinya bahwa siswa melakukan kenakalan tetapi ketertarikannya pada kegiatan organisasi kemasyarakatan tidaklah begitu anthusias. Bila diasumsikan dapat diperoleh semakin tinggi (positif94) ketertarikanya pada kegiatan OSIS semakin rendah (negatif-70) melakukan kenakalan. Elemen ikatan sosial terhadap kegiatan organisasi kemasyarakatan dapat dikatakan rendah. artinya anak yang melakukan perbuatan kenakalan tidak demikian intens tertarik pada kegiatan organisasi kemasyarakatan, karena waktu yang responden miliki sudah cukup tersita oleh kegiatan-kegiatan di sekolah.

Tabel 13. H U B U N G A N ANTARA KENAKALAN ANAK DENGAN INVOLVEMENT / KETERLIBATAN PADA KEGIATAN PRAMUKA 
(UDAYANA MASTER LAW JOURNAL)

\begin{tabular}{|c|c|c|c|c|c|}
\hline \multirow{2}{*}{$\begin{array}{c}\text { KETERLIBATAN } \\
\text { PADA } \\
\text { KEGIATAN } \\
\text { PRAMUKA }\end{array}$} & \multicolumn{2}{|c|}{ JENIS KENAKALAN } & \multirow[b]{2}{*}{ TOTAL } & \multirow[b]{2}{*}{ Qxy } & \multirow[b]{2}{*}{ KK/CC } \\
\hline & $\begin{array}{c}\text { Tindak } \\
\text { Kriminal }\end{array}$ & Kenakalan & & & \\
\hline NEGATIF & 76 (a) & 40 (b) & 116 & \multirow{3}{*}{$-0,59405$} & \multirow{3}{*}{$\begin{array}{c}\text { Hubungan } \\
\text { negatif yang } \\
\text { mantap }\end{array}$} \\
\hline POSITIF & 60 (c) & 124 (d) & 184 & & \\
\hline Jumlah & 136 & 164 & 300 & & \\
\hline
\end{tabular}

Paparan tabel di atas dikaitkan dengan Tabel Nilai Koefisien Korelasi diperoleh hubungan negatif yang mantap, artinya bahwa siswa pernah melakukan kenakalan, namun keterlibatannya pada kegiatan organisasi kepramukaan begitu anthusias dan mantap. Apalagi kegiatan kepramukaan ada unsur "penilaian" dari guru sebagai aktivitas kegiatan sekolah. Bila diasumsikan dapat diperoleh semakin tinggi (positif-124) keterlibatannya pada kegiatan kepramukaan maka semakin rendah (negatif-40) pulalah anak melakukan kenakalan. bila dicermati ikatan sosial terhadap kegiatan organisasi kepramukaan dapat dikatakan mantap. Sebab pada kegiatan kepramukaan manfaat untuk itu sangat besar sekali, banyak ajaran kebersamaan, keprihatinan, kerukunan, dan budhi pekerti diajarkan pada kegiatan tersebut.

Tabel 14. HUBUNGAN ANTARA KENAKALAN ANAK DENGAN INVOLVEMENT / KETERLIBATAN PADA KEGIATAN PENCINTA ALAM

\begin{tabular}{|c|c|c|c|c|c|}
\hline \multirow{2}{*}{$\begin{array}{c}\text { KETERLIBATAN } \\
\text { PADA KEGIATAN } \\
\text { PENCINTA } \\
\text { ALAM }\end{array}$} & \multicolumn{2}{|c|}{ JENIS KENAKALAN } & \multirow[b]{2}{*}{ TOTAL } & \multirow[b]{2}{*}{ Qxy } & \multirow[b]{2}{*}{$K K / C C$} \\
\hline & $\begin{array}{c}\text { Tindak } \\
\text { Kriminal }\end{array}$ & Kenakalan & & & \\
\hline NEGATIF & $80(a)$ & 47 (b) & 127 & \multirow{3}{*}{$-0,56104$} & \multirow{3}{*}{$\begin{array}{c}\text { Hubungan } \\
\text { negatif yang } \\
\text { mantap }\end{array}$} \\
\hline POSITIF & $56(c)$ & 117 (d) & 173 & & \\
\hline Jumlah & 136 & 164 & 300 & & \\
\hline
\end{tabular}

Tidak jauh berbeda dengan kegiatan kepramukaan pada uraian di atas, jika dikaitkan dengan Tabel Nilai Koefisien Korelasi diperoleh hubungan negatif yang mantap. Bila diasumsikan maka dapat diperoleh semakin tinggi (positif-117) keterlibatannya pada kegiatan pencinta alam maka semakin rendah (negatif-47) pulalah anak melakukan kenakalan. Bila dicermati ikatan sosial (social bond) terhadap kegiatan organisasi pencinta alam tersebut dapat dikatakan mantap. artinya anak yang melakukan perbuatan kenakalan tersebut tetap mantap pada kegiatan pencinta alam. Sebab pada kegiatan pencinta alam manfaat untuk itu sangat besar sekali, banyak ajaran kebersamaan, keprihatinan, kerukunan, dan budhi pekerti diajarkan pada kegiatan tersebut.

Tabel 15.

HUBUNGAN ANTARA KENAKALAN ANAK DENGAN INVOLVEMENT / KETERLIBATANNYA PADA KEGIATAN KESENIAN

\begin{tabular}{|c|c|c|c|c|c|}
\hline \multirow{2}{*}{$\begin{array}{c}\text { KETERLIBATAN } \\
\text { PADA KEGIATAN } \\
\text { KESENIAN }\end{array}$} & \multicolumn{2}{|c|}{ JENIS KENAKALAN } & \multirow[b]{2}{*}{ TOTAL } & \multirow[b]{2}{*}{ Qxy } & \multirow[b]{2}{*}{ KK/CC } \\
\hline & $\begin{array}{c}\text { Tindak } \\
\text { Kriminal }\end{array}$ & Kenakalan & & & \\
\hline NEGATIF & 78 (a) & 32 (b) & 120 & \multirow{3}{*}{$-0,69454$} & \multirow{3}{*}{$\begin{array}{l}\text { Hubungan } \\
\text { negatif yang } \\
\text { sangat kuat }\end{array}$} \\
\hline POSITIF & $58(c)$ & 132 (d) & 180 & & \\
\hline Jumlah & 136 & 164 & 300 & & \\
\hline
\end{tabular}

Tidak jauh berbeda dengan kegiatan kepramukaan dan pencinta alam, pada uraian di atas, maka diperoleh hubungan negatif yang sangat kuat, artinya bahwa siswa walaupun pernah melakukan kenakalan, namun keterlibatannya pada kegiatan kesenian begitu sangat kuat. Bila 
diasumsikan maka dapat diperoleh semakin tinggi (positif-132) keterlibatannya pada kegiatan kesenian maka semakin rendah (negatif-32) anak melakukan kenakalan atau penyimpangan. Elemen ikatan sosial (social bond) terhadap kegiatan kesenian tersebut dapat dikatakan sangat kuat, artinya walau anak melakukan perbuatan penyimpangan atau kenakalan, korelasinya anak sangat kuat di dalam kegiatan kesenian, akan mengurangi bahkan menghilangkan keinginan untuk melakukan kenakalan.

Tabel 16.

HUBUNGAN ANTARA KENAKALAN ANAK DENGAN INVOLVEMENT / KETERLIBATANNYA PADA KEGIATAN OLAH RAGA

\begin{tabular}{|c|c|c|c|c|c|}
\hline \multirow{2}{*}{$\begin{array}{c}\text { KETERLIBATAN } \\
\text { PADA KEGIATAN } \\
\text { OLAH RAGA }\end{array}$} & \multicolumn{2}{|c|}{ JENIS KENAKALAN } & \multirow[b]{2}{*}{ TOTAL } & \multirow[b]{2}{*}{ Qxy } & \multirow[b]{2}{*}{$K K / C C$} \\
\hline & $\begin{array}{l}\text { Tindak } \\
\text { Kriminal }\end{array}$ & Kenakalan & & & \\
\hline NEGATIF & 74 (a) & 70 (b) & 144 & \multirow{3}{*}{$-0,23159$} & \multirow{3}{*}{$\begin{array}{l}\text { Hubungan } \\
\text { negatif yang } \\
\text { rendah }\end{array}$} \\
\hline POSITIF & $62(c)$ & 94 (d) & 156 & & \\
\hline Jumlah & 136 & 164 & 300 & & \\
\hline
\end{tabular}

Tabel di atas dihubungkan Tabel Nilai Koefisien Korelasi maka diperoleh hubungan negatif yang rendah, artinya bahwa siswa pernah melakukan kenakalan anak, namun keterlibatannya pada kegiatan olah raga begitu rendah. Bila diasumsikan maka dapat diperoleh semakin tinggi (positif-94) keterlibatannya pada kegiatan olah raga maka semakin rendah (negatif-70) anak melakukan kenakalan. Namun bila dicermati ikatan sosial (social bond) terhadap kegiatan olah raga tersebut dapat dikatakan rendah, artinya anak yang melakukan perbuatan kenakalan tetap rendah di dalam aktivitas keterlibatannya pada olah raga.

Pada uraian di bawah ini akan di bahas mengenai elemen ikatan sosial dari Hirschi yang terakhir yakni Belief atau keyakinan pada norma adat dan norma hukum. Sedangkan keyakinan pada (2) norma agama yang terurai pada keyakinan bila terjadi pelanggaran adat maka para pelanggarnya akan dikenakan sanksi adat, demikian pula bila terjadi pelanggaran hukum maka pelanggaranya dikenakan sanksi hukum.

Di bawah ini dikemukakan dan selanjutnya dianalisis mengenai korelasi terhahap keyakinan pada ajaran norma adat yang ada di Bali. Di mulai dari keyakinan akan ajaran Tri Hita Karana.

Tabel 17. HUBUNGAN ANTARA KENAKALANANAKDENGANBELIEF / KEYAKINAN PADA AJARAN TRI HITA KARANA

\begin{tabular}{|c|c|c|c|c|c|}
\hline \multirow{2}{*}{$\begin{array}{l}\text { KEYAKINANPADA } \\
\text { AJARAN TRI HTA } \\
\text { KARANA }\end{array}$} & \multicolumn{2}{|c|}{ JENIS KENAKALAN } & \multirow[b]{2}{*}{ TOTAL } & \multirow[b]{2}{*}{ Qxy } & \multirow[b]{2}{*}{$K K / C C$} \\
\hline & $\begin{array}{l}\text { Tindak } \\
\text { Kriminal }\end{array}$ & Kenakalan & & & \\
\hline LEMAH & 71 (a) & 22 (b) & 930 & \multirow{3}{*}{$-0,75156$} & \multirow{3}{*}{$\begin{array}{l}\text { Hubungan } \\
\text { negatif yan } \\
\text { sangat kua }\end{array}$} \\
\hline KUAT & 65 (c) & 142 (d) & 207 & & \\
\hline Jumlah & 136 & 164 & 300 & & \\
\hline
\end{tabular}

Hubungan antara keyakinan pada ajaran Tri Hita Karana dengan kenakalan anak diperoleh hubungan negatif yang sangat kuat, artinya bahwa siswa walau pernah melakukan kenakalan anak, namun keyakinannya pada ajaran Tri Hita Karana begitu sangat kuat. Hal ini bila diasumsikan maka dapat diperoleh hipotesis bahwa semakin tinggi (kuat-142) 
keyakinannya pada ajaran Tri Hita Karana, maka semakin rendah (lemah-22) anak melakukan kenakalan atau penyimpangan. Bila dicermati ikatan sosial (social bond) terhadap keyakinan melaksanakan ajaran tri hita karana, dapat dikatakan mantap, korelasinya adalah anak sangat kuat di dalam keyakinan melaksanakan ajaran Tri Hita Karana, dengan demikian akan mengurangi bahkan menghilangkan keinginan untuk melakukan kenakalan anak.

Tabel 18. HUBUNGAN ANTARA KENAKALANANAKDENGANBELIEF / KEYAKINAN PARA PELANGGAR HUKUM DIKENAKAN

\begin{tabular}{|c|c|c|c|c|c|}
\hline \multirow{2}{*}{$\begin{array}{l}\text { KEYAKINAN } \\
\text { PELANGGAR } \\
\text { HUKUM } \\
\text { DIKENAKAN } \\
\text { SANKSI } \\
\text { HUKUM }\end{array}$} & \multicolumn{2}{|c|}{ JENIS KENAKALAN } & \multirow{2}{*}{ TOTAL } & \multirow[b]{2}{*}{ Qxy } & \multirow[b]{2}{*}{ KK/CC } \\
\hline & $\begin{array}{l}\text { Tindak } \\
\text { Kriminal }\end{array}$ & Kenakalan & & & \\
\hline LEMAH & 81 (a) & 45 (b) & 126 & \multirow{3}{*}{$-0,5621$} & \multirow{3}{*}{$\begin{array}{c}\text { Hubungan } \\
\text { negatif yang } \\
\text { mantap }\end{array}$} \\
\hline KUAT & 55 (c) & 109 (d) & 164 & & \\
\hline Jumlah & 136 & 164 & 300 & & \\
\hline
\end{tabular}

Hubungan antara keyakinan para pelanggar hukum dikenakan sanksi hukum dengan kenakalan anak diperoleh hubungan negatifyang sangat kuat, artinya bahwa siswa walau pernah melakukan penyimpangan sosial atau kenakalan anak, namun keyakinan bahwa para pelanggar hukum dikenakan sanksi hukum begitu mantap di kalangan responden siswa di Bali. Hal ini bila diasumsikan maka dapat diperoleh hipotesis bahwa semakin tinggi (kuat-109) keyakinan para pelanggar hukum dikenakan sanksi hukum, maka semakin rendah (lemah-45) anak melakukan kenakalan.
Tabel 19. HUBUNGAN ANTARA KENAKALANANAKDENGANBELIEF / KEYAKINAN PARA PELANGGAR ADAT DIKENAKAN SANKSI ADAT

\begin{tabular}{|c|c|c|c|c|c|}
\hline \multirow{2}{*}{$\begin{array}{c}\text { KEYAKINAN } \\
\text { PARA } \\
\text { PELANGGAR } \\
\text { ADAT } \\
\text { DIKENAKAN } \\
\text { SANKSI } \\
\text { ADAT }\end{array}$} & \multicolumn{2}{|c|}{ JENIS KENAKALAN } & \multirow[b]{2}{*}{ TOTAL } & \multirow[b]{2}{*}{$Q x y$} & \multirow[b]{2}{*}{ KK/CC } \\
\hline & $\begin{array}{l}\text { Tindak } \\
\text { Kriminal }\end{array}$ & Kenakalan & & & \\
\hline LEMAH & 75 (a) & 42 (b) & 127 & \multirow{3}{*}{$-0,49824$} & \multirow{3}{*}{$\begin{array}{l}\text { Hubungan } \\
\text { negatif yang } \\
\text { sedang }\end{array}$} \\
\hline KUAT & 61 (c) & 102 (d) & 163 & & \\
\hline Jumlah & 136 & 164 & 300 & & \\
\hline
\end{tabular}

Hubungan antara keyakinan para pelanggar adat dikenakan sanksi adat dengan kenakalan anak diperoleh hubungan negatif yang sedang, artinya bahwa siswa walau pernah melakukan kenakalan anak, namun keyakinan bahwa para pelanggar adat dikenakan sanksi adat biasa saja (sedang) di kalangan responden siswa di Bali, artinya sanksi adat yang dimaksudkan oleh responden belumlah nyata di lihat pada kenyataannya. Bila diasumsikan maka dapat diperoleh hipotesis bahwa semakin tinggi (kuat-102) keyakinan para pelanggar hukum dikenakan sanksi hukum, maka semakin rendah (lemah-42) anak melakukan kenakalan.

\section{c. Teori Kontrol Sosial dapat digunakan sebagai landasan kebijakan menanggulangi}

\section{Kenakalan Anak di Bali}

Teori Kontrol Sosial berangkat dari suatu asumsi bahwa individu di masyarakat mempunyai kecendrungan yang sama kemungkinannya, menjadi "baik" atau “jahat”. Baik jahatnya seseorang sepenuhnya 
tergantung pada masyarakatnya. Ia menjadi baik kalau saja masyarakatnya membuatnya demikian, dan menjadi jahat apabila masyarakatnya membuatnya demikian ${ }^{7}$. Di samping perbedaan dalam menjelaskan kejahatan namun secara hakiki teori kontrol sosial tidak sama halnya dengan teori-teori kriminologi pada umumnya yang berangkat dari pertanyaan dasaryang dilontarkan paham ini berkaitan dengan unsur-unsur pencegah yang mampu menangkal timbulnya perilaku delinkuen di kalangan anggota masyarakat, utamanya para remaja, dri pertanyaan dasar "apa yang membuat orang menjadi jahat"?, Teori kontrol sosial berangkat dari pertanyaan dasar yang harus memperoleh kejelasan lewat teori itu, pertanyaan dasar itu adalah "Mengapa kita patuh dan taat pada norma-norma masyarakat" atau "Mengapa kita tidak melakukan penyimpangan?". Pertanyaan dasar di atas mencerminkan suatu pemikiran bahwa penyimpangan bukan merupakan problematika, yang dipandang sebagai persoalan pokok adalah ketaatan atau kepatuhan pada norma-norma kemasyarakatan.

Menurut Travis Hirschi ${ }^{8}$, ada empat elemen ikatan sosial (social bond) yang terdapat dalam setiap masyarakat yakni :

Pertama, Attachment adalah kemampuan manusia untuk melibatkan dirinya terhadap orang lain. Kalau attachment

John Hagan, Op.cit hlm 164

William III \& McShane, opcit, hlm 113. Lihat Stuart H Traub and Craig B.Little, Theories of Devience, Third Edition, State University of New York, 1985, hlm.257. Lihat pula JE Sahetapy, Teori Kriminologi Suatu Pengantar, Bandung : Citra Aditya Bakti, 1992, hlm.20. ini sudah terbentuk, maka orang tersebut akan peka terhadap pikiran, perasaan, dan kehendak orang lain.

Attachment sering diartikan secara bebas dengan keterikatan. Ikatan pertama yaitu keterikatan dengan orang tua, keterikatan dengan sekolah (guru), dan keterikatan dengan teman sebaya.

Menurut Hirschi, remaja yang sudah cukup terikat dengan orang tua mampu menahan diri untuk tidak melakukan pelanggaran karena hal itu berakibat buruk terhadap hubungan mereka. Jadi ikatan kasih sayang antara orang tua dan anak yang merupakan penghalang utama bagi mereka untuk melakukan tindak kriminal. Kekuatan keterikatan/hubungan itu tergantung pada dalam dan kualitas interaksi antara orang tua dan anak tersebut. Ikatan orang tua-anak ini merupakan tempat menyalurkan ide-ide konvensional maupun harapan-harapan 9

Kedua, Commitment adalahketerikatan seseorang pada sub sistem konvensional seperti sekolah, pekerjaan, organisasi, dan sebagainya. Komitmen merupakan aspek rasional yang ada dalam ikatan sosial. Segala kegiatan yang dilakukan oleh seseorang individu seperti sekolah, pekerjaan, kegiatan dalam organisasi akan mendatangkan manfaat bagi orang tersebut. Manfaat tersebut dapat berupa harta benda, reputasi, masa depan, dan sebagainya. Terlebih lagi jika investasi tersebut menghasilkan keuntungankeuntungan yang diharapkan. Tetapi jika investasi tersebut tidak menghasilkan apaapa, maka orang akan mengkalkulasikan

Freda Adler, et all, Op.cit, hlm. 162 
untung rugi dari perbuatan penyimpangan yang dilakukan.

Ketiga, Involvement, merupakan aktivitas seseorang dalam subsistem. Jika seseorang berperan aktif dalam organisasi maka kecil kecenderungannya untuk melakukanpenyimpangan.Logikapengertian ini adalah bila orang aktif di segala kegiatan maka orang tersebut akan menghabiskan waktu dan tenaganya dalam kegiatan tersebut. Sehingga dia tidak sempat lagi memikirkan hal-hal yang bertentangan dengan hukum. Dengan demikian segala aktivitas yang dapat memberi manfaat, akan mencegah orang itu untuk melakukan perbuatan yang bertentangan dengan hukum. Orang yang sibuk dengan kegiatan konvensional akan memiliki lebih banyak waktu untuk tidak melakukan tindak pelanggaran ${ }^{10}$.

Keempat, Belief, merupakan aspek moral yang terdapat dalam ikatan sosial, yang tentunya berbeda dengan ketiga aspek di atas. Beliefs, merupakan kepercayaan seseorang pada nilai-nilai moral yang ada. Kepercayaan seseorang terhadap normanorma yang ada menimbulkan kepatuhan terhadap norma tersebut. Kepatuhan terhadap norma tersebut tentunya akan mengurangi hasrat untuk melanggar. Tetapi bila orang tidak mematuhi norma-norma maka lebih besar kemungkinan melakukan pelanggaran.

Menurut Freda Adler, Hirschi menyimpulkan hasil penelitiannya bahwa

$10 \quad$ Freda Adler, Op.cit, hlm 163 bila remaja-remaja tersebut sudah tidak percaya lagi hukum itu sebagai alat untuk mendapatkankeadilan,keamanan, ketertiban, dan kedamaian, maka ikatan mereka dengan masyarakat akan lemah, dan kemungkinan mereka untuk melakukan tindak kriminal meningkat ${ }^{11}$.

Pandangan Frank E. Hagan ${ }^{12}$, di mana pada dasarnya menyatakan bahwa delinkuen itu terjadi pada saat keterikatan seseorang dengan masyarakat melemah atau rusak. Seseorang mempertahankan penyesuaian atas ketakutan akan kejahatan yang berakibat memecah hubungan mereka dengan keluarga, teman, tetangga, pekerjaan, sekolah, dan sejenisnya. Pada intinya, seseorang menyesuaikan diri bukanlah karena takut atas hukuman yang telah ditetapkan dalam hukum pidana, tetapi lebih banyak karena kepedulian terhadap kejahatan, adat-istiadat, dan citra perorangan dari mereka yang memiliki kelompok penting dalam masyarakat di mana mereka menjadi anggotanya. Keterikatan pada masyarakat itu terdiri atas empat komponen : yakni attachment, commitment, involvement, and belief.

Seperti halnya yang terjadi di Bali, pelaku kenakalan anak yang diteliti di Bali sebenarnya anak-anak sangat taat dan soleh, juga didukung dengan ikatan sosial yang kuat dengan aktivitas sosial yang tinggi, ditelusuri mengapa hal tersebut yang sudah demikian erat ikatan sosialnya dapat menjadi rapuh

Freda Adler, Op.cit, hlm 163

Frank E. Hagan, Op.cit, hlm. 450 
dengan banyaknya kasus-kasus kenakalan anak, untuk itulah sangat wajar hal tersebut dikaji menurut teori Kontrol Sosial. Walau disadari bahwa semula teori kontrol ini lebih banyak membahas masalah kenakalan remaja bagi sebagian siswa-siswa sekolah tingkat atas di Amerika, namun perkembangan selanjutnya juga telah diadakan penelitian di Bali.

Kajian kenakalan anak yang terjadi di Bali dicoba dianalisis dengan pendekatan teori kriminologi yakni teori kontrol sosial yang dikemukakan oleh Travis Hirschi(1969) Guru Besar tetap Sosiologi di Univercity of Arizona. Penggunaan teori kontrol sosial dalam penelitian ini dilandaskan pada kenyataan bahwa kultur (budaya) masyarakat Indonesia (khususnya Bali) masih menjunjung tinggi norma kesusilaan dan tata krama adat ketimuran. Keempat elemen itu, berpengaruh pada erat tidaknya ikatan sosial para anak-anak/ remaja pada masyarakat. Sejauh individu memperlihatkan ikatan sosial pada masyarakat, pertanyaan yang muncul di kalangan pakar kriminologi adalah bagaimana ikatan-ikatan itu dapat melemah atau terputus yang pada akhirnya melahirkan perilaku delinkuen. Begitu salah satu dari keempat unsur itu melemah atas diri seseorang, maka seseorang itu akan "terbebas" dan kecenderungannya orang itu untuk terlibat dalam perilaku delinkuen pun meningkat.

Dari uraian di atas dapat disimpulkan bahwa teori kontrol sosial dapat digunakan sebagai landasan untuk menanggulangi kenakalan anak, mengingat secara rinci telah menguraikan suatu ikatan sosial yang nampak jelas dari elemen-elemen kontrol sosial seperti attachment, commitment, involvement, dan belief. Keterikatan terhadap anak remaja pada satu individu dengan individu lainnya, apakah itu peer-group, sekolah tokoh masyarakat, tokoh agama, kehidupan sehari-hari dan suatu organisasi kemasyaraklatan, dan manfaat yang sudah nyata dapat diterima dengan baik hasilnya, ditunjang dengan ketaatan pada hukum dan agama, maka tak pelak teori kontrol sosial ini dapat digunakan sebagai landasan untuk menanggulangi kenakalan anak. Apalagi teori ini dikaitkan dengan budaya masyarakat Bali dengan kearifan lokalnya seperti Tri Hita Karana, merupakan kearifan lokal dalam pola penanggulangan kenakalan anak tersebut.

\section{c. Upaya Penanggulangan Kenakalan Anak melalui Kearifan Lokal Bali}

Kearifan lokal adalah cara bersikap dan bertindak seseorang atau sekelompok orang untuk merespon perubahan-perubahan yang khas dalam lingkup lingkungan flsik maupun kultural. Kearifan lokal apabila dilihat dari fungsi dan wujudnya dapat dipahami sebagai usaha manusia dengan menggunakan akal budinya (kognisi) untuk bertindak dan bersikap terhadap sesuatu, objek, atau peristiwa yang terjadi dalam ruang tertentu. Pengertian di atas, disusun secara etimologi, dimana wisdom dipahami sebagai kemampuan seseorang dalam menggunakan akal pikirannya dalam bertindak atau bersikap sebagai hasil penilaian terhadap 
sesuatu, objek, atau peristiwa yang terjadi. Sebagai sebuah istilah wisdom sering diartikan sebagai "kearifan/kebijakan". ${ }^{13}$

Sebagai falsafah hidup yang unik, Tri Hita Karana, yang berakar pada agama Hindu Bali mengajarkan nilai-nilai dan praktek universal untuk mencapai kemakmuran, kedamaian dan kebahagiaan melalui keseimbangan dan keharmonisan antara dunia-dunia spiritual, sosial dan natural. Setiap dunia ini memiliki suatu rangkaian pengetahuan, kepercayaan dan tindak laku yang harus dipatuhi untuk mencapai keseimbangan dan keharmonisan di antara dan di dalam dunia-dunia ini, dengan dunia manusia berada di tengahtengah keseimbangan ini. Keranjingan Bali terhadap keseimbangan dan keharmonisan bukan saja merupakan konsep pasif, tetapi merupakan falsafah yang menekankan keseimbangan yang dinamis (dynamic equlibrium). Dalam hal terjadi kekuatan yang bertabrakan, di mana keseimbangan yang ada runtuh dan terjadi ketidakseimbangan, maka kekacauan yang menyusul akan mewujudkan keseimbangan dan keharmonisan baru yang bahkan lebih dinamis yang diharapkan mampu menunjang pemgganti sosial dari zaman yang berubah.

Konsep Tri Hita Karana tidak akan efektif dalam peranan pelestariannya tanpa adanya dukungan penting dari institusiinstitusi tradisional, yang terpenting adalah desa adat, banjar dan subak. Setiap

13 Ridwan, Nurma Ali. 2007. Landasan Keilmuan Kearifan Lokal, Jurnal Ibda Vol.5 No. I. P3M STAIN. Purwokerto. institusi ini adalah replika dari konsep Tri Hita Karana dan masing-masing memiliki tempat ibadahnya; berupa pura, anggotanya dan daerahnya yang mencerminkan ketiga hubungan konsep tersebut dengar Tuhan (parhyangan), sesama manusia (pawongan) dan alam (palemahan).

Dari pemaparan di atas jelaslah bahwa dengan filosofi Tri Hita Karana yang diaplikasikan dalam berbagai kegiatan seperti Panca Sradha, Panca Yadnya, Tat twam Asi, ajaran Karmaphala, dapat digunakan untuk menanggulangi kenakalan anak yang berbasis kearifan lokal masyarakat Bali.

\section{BAB V SIMPULAN DAN SARAN}

\section{A. SIMPULAN}

1. Hal ini dapat dianalisis dari proposisi yang ada yang bahwa: preposisi terhadap teori kontrol sosial dikaitkan dengan kenakalan anak maka dapat diperoleh gambaran sebagai berikut :

1. Semakin kuat keterikatan seorang anak dengan orang tua, guru, kegiatan konvensional,peer-group, tokohagama maupun tokoh masyarakat, maka semakin rendah kecenderungan anak terlibat dalam perilaku menyimpang;

2. semakin positif ketertarikan anak terhadap organisasi siswa intra sekolah, sekeha teruna, dan organisasi kemasyarakatan lainnya, maka semakin negatif kecenderungan anak terlibat dalam perilaku delinkuen;

3. semakin positif keterlibatan anak dengan kegiatan pramuka, pencinta alam, kesenian, olah raga, maka 
semakin negatif kecenderungan anak untuk terlibat dalam perilaku delinkuen;

4. semakin kuat keyakinan/kepatuhan anak pada norma adat dan norma hukum, maka semakin lemah/rendah anak terlibat dalam kenakalan anak.

2. Dari pemaparan di atas jelaslah bahwa dengan filosofi Tri Hita Karana yang diaplikasikan dalam berbagai kegiatan seperti Panca Sradha, Panca Yadnya, Tat twam Asi, ajaran Karmaphala, dapat digunakan untuk menanggulangi kenakalan anak yang berbasis kearifan lokal masyarakat Bali.

\section{B. SARAN}

a. Bahwa teori Barat tidak selama tepat pula diterapkan pada masyarakat lainnya khususnya di Bali. Banyak hal yang tidak dilakukan Hirschi, namun pada masyarakat Bali, keterikatan, keterlibatan, dan keyakinan sesuatu dalam ikatan sosial itu lebih banyak bernuansa adat dan agama. Metode yang digunakan Travis Hirschi adalah self report study yang selamanya tidak tepat digunakan pada masyarakat yang menjunjung adat ketimuran, untuk itu metode self report study sangat dibantu dengan observasi maupun dengan wawancara;

b. Karena Hirschi telah mempopulerkan teori Kontrol Sosial dengan elemen social bond nya akan lebih tepat ditambahkan dengan Teori Kontrol Sosial berbasis Budaya yang bersesuian dengan budaya masyarakat
Bali. Dalam konteks memahami kontrol sosial berupa ikatan sosial tesebut maka tidak dapat dilepaskan dari konteks budaya masyarakat Bali. Ikatan sosial baik berupa attachment, involvement, commitment, dan belief dengan didukung oleh kearifan lokal masyarakat Bali seperti ajaran Tri Hita Karana, Tri Kaya Parisudha, Tat Twam Asi, Karmaphala, Catur Guru dan sebagainya, sangat memberi pedoman di dalam bertingkah laku dalam keseharian, sehingga bila dikaitkan dengan elemen kontrol sosial dari Travis Hirschi di mana kehidupan remaja pada masyarakat di Amerika Serikat, tentu akan berbeda nilai kepatuhannya pada masyarakat berbudaya seperti pada masyarakat Bali pada khususnya dan budaya Indonesia pada umumnya.

\section{DAFTAR PUSTAKA}

\section{A. Literatur / Buku}

Alo Liliweri, 2006. Kearifan Lokal Sebagai Kearifan Orang Miskin dalam Keberagaman. Makalah disajikan dalam dialog Budaya NTT pada tanggal 26 September 2006.

A. Syamsudin Meliala dan E. Sumarsono. 1985. Kejahatan Anak: Suatu Tinjauan dari Psikologi dan Hukum. Jogjakarta: Liberty.

Barda Nawawi Arief, 1996. Bunga Rampai Kebijakan Hukum Pidana, Bandung, Alumni. 
Edwin H Sutherland, 1995. Principle of Criminology, revised by Donald $R$ Creseey, Philadelphia; JB Lipincolt Co,

Frank. E Hagan. 1987. Introduction to Criminology, Theories, Methodes, and Criminal Behavior, Nelson-Hall Chicago.

Frank E Hagan, 1989. Introduction to Criminology, Theories, Methodes, and Criminal Behavior, Nelson-Hall Chicago

Fritjop Capra, 2002. Titik Balik Peradaban Sain, Masyarakat dan Kebangkitan Kebudayaan. Terjemahan oleh M. Thoyibi, Bentang Budaya. Yogyakarta.

Freda Adler; Gerhard O.W Mueller; William S Laufer. 1995. Criminology: The Shorter Version, Second Edition, McGraw-Hill, Inc, USA .

Geriya,IWayan. 2004. Kearifan LokalDalam Perspektif Kajian Budaya: Pergulatan Teoritik dan Ranah Aplikatif. Program Magsiter Kajian Budaya. Universitas Udayana. Denpasar.

Hagan, John 1987. Modern Criminology, Crime, Criminal Behavior and its Control, Singapore, McGraw Hill Book Com.

Hagan, Frank. E. 1989. Introduction to Criminology, Theories, Methodes, and Criminal Behavior, Nelson-Hall Chicago

Hirschi, Travis. 1969. Causes of Delinquency, Berkeley, University of California, Press
Hofnagels, G. Peter. 1973. The Other Side of Criminology, Kluwer Deventer, Holland

Irma Setyowati Soeniitri,1990. Aspek Hukum Perlindungan Anak, Bumi Aksara, Jakarta.

Jack E.Bynum and William E.Thomson, 2007. Juvenile Delinquency: A Sociological Approach. Published in the United States of Amerika, Pearson Education, Inc.

Kartini Kartono, 1992. Patologi Sosial (2) Kenakalan Remaja, Jakarta, Rajawali Pers.

1995. Psikologi Anak (Psikologi Perkembangan) Bandung: Mandar Maju.

Lexi Moleong, 1989. Metode Penelitian Kualitatif. Bandung, Penerbit Remaja.

Muhammad Mustofa, 2005. Metode Penelitian Kriminologi, Penerbit Fakultas Ilmu Sosial dan Ilmu Politik Univ. Indonesia (FISIP - UI Press).

Muladi, 1995. Kapita Selekta Sistem Peradilan Pidana, PenerbitUniversitas Diponegoro, Semarang

PaulusHadisuprapto,2008.DelinkuensiAnak, Pemahaman dan Penanggulangannya, Penerbit Bayu Media Publishing.

Romli Atmasasmita, 1984. Problema Kenakalan Anak dan Remaja, Bandung, Armico,

Satjipto Rahardjo, 1974. Beberapa Segi dan Studi tentang Hukum dan Masyarakat, Hukum no. 1 Tahun I, 1974, Jakarta, Yayasan Penelitian dan Pengembangan Hukum. 
(UDAYANA MASTER LAW JOURNAL)

Semadi Astra. 2004. Revitalisasi Kearifan

Lokal Dalam Upaya memperkokoh

Jati Diri Bangsa Dalam Politik

Kebudayaan dan Identitas Etnik.

Fakultas sastra Universitas Udayana

Denpasar.

Soetandyo Wignjosoebroto, 2007. Disertasi:

Sebuah Pedoman Ringkas Tentang

Tatacara Penulisannya, Lab. Sosiologi

FISIP Airlangga.

Sudarsono, 1991. Kenakalan Remaja,

Jakarta: Rineka Cipta.

Sudarto, 1977. Hukum dan Hukum Pidana, Penerbt Alumni, Bandung.

Sutrisno Hadi. Statistik 2, 1986. Yogjakarta :

Fakultas Psikologi Universitas Gadjah

Mada.

Stuart H.Traub \& Craig B Little, 1985.

Theories of Devience, Third Edition,

F.E Peacock Publishers, Inc, USA.

Travish Hirschi, 1969. Causes of Delinquency, University of California Press, Berkeley, Los Angeles, and London.

William III, Frank.P \& Marilyn McShane 1988. Criminological Theory, Prince Hall, New Jersey. 